\title{
She's Got the Power
}

Tim Reynolds

Pomona College, Class of 2015

The blazon is a poetic form characterized by a lyric catalogue of the admirable physical features of the poet's beloved. Reading this catalogue as a form of dismemberment, Nancy Vickers and Patricia Parker argue that the blazon exists as a tool for controlling and objectifying the beloved. Under Vickers' argument, the male poet's act of dismembering the female beloved protects him from the transformative dismemberment that Actaeon suffered at Diana's hands (Vickers, "Diana" 273). Meanwhile, Parker explores how the blazon is utilized as a tool for figurative rape, assault, and commodification (Parker 132). Both argue that the blazon features an oppressive power dynamic in which a controlling male-dominant order (defined by its embodiment in the male poet-as-Actaeon) dismembers the female beloved-as-Diana's physical body, making her into a voiceless, powerless object. And yet, this oppressive power dynamic does not escape subversive forces, as demonstrated by Dahlia Ravikovitch's "Clockwork Doll." Ravikovitch's poem subverts the blazon's oppressive power dynamic through a three-step process: resistance via movement, partial physical liberation, and empowerment through transformation. Ravikovitch's doll actively resists the blazon's oppressive power dynamic by literally moving. Because this movement defies the power dynamic's rigid constraints, it brings about partial liberation from that power dynamic. This partial liberation, in turn, allows Ravikovitch's doll to empower herself by co-opting dismemberment and its transformative power, removing her from the blazon's power dynamic.

Because the poet catalogues the doll's physical features, "Clockwork Doll" demonstrates that it is a blazon. In identifying Petrarch's adaptation of Ovidian myth as the model for future blazons, Vickers indicates that the poet-as-Actaeon "cannot allow [the beloved-as-Diana] to dismember his body; instead he repeatedly, although reverently, scatters hers throughout his scattered rhymes" ("Diana" 279), a process Parker relates to the act of taking inventory (131). In "Clockwork Doll," the poet takes inventory of the doll's physical features: "And my hair was golden, my eyes were blue, / and my dress was the color of flowers and all, / and a sprig of cherries was tacked to my hat" (Ravikovitch lines 12-14). Though not particularly complex, this analysis places "Clockwork Doll" firmly within the tradition of the blazon, a tradition it will subsequently subvert.

\footnotetext{
${ }^{1}$ I would like to thank Prof. Colleen Rosenfeld, Emily Miner, and Katherine Snell for their instrumental help in this paper's development.

${ }^{2}$ Unless otherwise noted, I will use Chana Bloch and Ariel Bloch's translation.
} 
Ravikovitch's poem, through its inventory of the stereotypical doll, initially seems to fully subscribe to the conventional model of the blazon (and its attendant power dynamic). The poet describes her beloved (i.e. herself) as a "clockwork doll," a mechanical, man-made object that "literalizes the stereotype of the 'doll,' which in both Hebrew and English slang of the 1950s refers to a pretty young woman" (Bloch and Kronfeld 265). And, Ravikovitch's doll, featuring Barbie-like golden hair, blue eyes, and a floral dress, reinforces this literal objectification of a 1950s ideal of female beauty. This stereotypical objectification seemingly identifies "Clockwork Doll" as a conventional blazon, with an oppressive power dynamic defined by the poet's control over the beloved doll.

And yet, Ravikovitch conflates the poet and the beloved as one and the same. In doing so, Ravikovitch's “Clockwork Doll” grants a voice to the traditionally voiceless beloved. In discussing the archetypal blazon, Vickers explains that "a lyric 'I' does not privately speak to a lyric 'you' but rather ... 'I' speaks 'you' to an audience” (Vickers, “The Blazon” 97). Yet for Ravikovitch's blazon, the doll is both the lyric "I" and the beloved "you," granting her a voice despite the notion that "bodies fetishized by a poetic voice logically do not have a voice of their own" (Vickers 277). The archetypal blazon features a male poet who lyrically dismembers his beloved; the poet's unilateral control of language is the source of his power. In featuring a voiced beloved who now has lyric control, "Clockwork Doll" subverts this power dynamic.

Because the beloved doll has a voice, her status as a literal object and her stereotypical appearance now take on new significance. As discussed above, Ravikovitch's doll entirely epitomizes female objectification, yet she can (and does) speak. The doll's voice is the first indication of her capacity to resist the blazon's oppressive power dynamic. More importantly, if Actaeon's poetic dismemberment of Diana removes her power (as Vickers argues), then the doll's dismemberment of her stereotypical self similarly strips the "doll" stereotype of its power as a supposed ideal. This act of dismembering the stereotype not only hints at the doll's capability to coopt dismemberment for her own ends (here, the subversion of a stereotype), but it also establishes the doll as an entity at odds with an oppressive, male-dominant order and its accompanying power dynamic. But how does this oppressive order manifest itself in "Clockwork Doll"?

The oppressive order first appears through the poem's form. As a sonnet, "Clockwork Doll" submits itself to a highly structured system of rhyme and meter. In fact, in its original Hebrew, Ravikovitch's poem is "a closely rhymed sonnet [with] ... perfect outer form" (Bloch and Kronfeld 265), paralleling the male-dominant order's rigid control. Despite the fact that the doll-as-poet has a voice, her poem's constraining form seems to nevertheless limit her lyric freedom.

Within the poem's text, the oppressive order, personified as the faceless, nameless "they" $(4,10)$, assumes the role of the "active buyer" of Ravikovitch's doll. The doll, as both poet and beloved, fulfills the roles of both the "active seller, and [the] passive object for sale" (Vickers, "The Blazon" 97). "They" are the ones whom the doll tries to impress by making her "manner ... nice and polite" (6) and by ensuring that her "steps [are] measured and true" (11). Indeed, an 
initial reading of "Clockwork Doll" features a doll continually trying and seemingly failing to meet "their" standards, always attempting to advertise her merits. Bolstering this interpretation, "they cast [her] aside" (10) when she "went out to dance" (9); "they" (i.e. the oppressive order) would have the doll be an object and nothing more. The doll's steps are, in fact, "measured and true" (11), but "they" would not even have her dance in the first place. These limits imposed on physical movement recall the aforementioned formal limits imposed on lyric freedom. Yet "they" already control and own her; the purchasing process, for which the blazon ostensibly exists, has already occurred. Thus, Ravikovitch's poem must exist for another purpose, namely the subversion of the blazon's oppressive power dynamic.

Beginning the process of subverting the blazon's power dynamic, Ravikovitch's doll rejects the power dynamic's constraints by actively moving. "I turned round and around" (2) is active movement set apart from her preceding objectified state as a clockwork doll by the phrase "but then" (1). An initial reading would interpret this turning as a mechanical doll's pirouetting, seemingly in line with a doll's role. But "they" do not turn the doll; instead, she turns herself. Furthermore, Burnshaw, Glassman, and Carmi's literal translation ${ }^{3}$ has her turning "to the right and to the left, in all directions" (192), phrasing that does not imply the rigid, controlled order of turning around in a circle. Ravikovitch's doll thus resists a portion of the power dynamic that "they" impose. As discussed above, "they" do not want the doll to move, preferring rigid objectification, and yet she moves anyway, introducing movement as a basic form of resistance.

This initial act of resistance via intentional, active movement leads to a small degree of physical liberation from the oppressive order's control. After she "turned round and around" (2), Ravikovitch's doll "fell on [her] face" (3). This (admittedly minor) physical displacement from upright to fallen attains new significance in light of an oppressive order that would not have the doll move at all. Here, the doll's movement leads to a change in physical position, a blatant refusal to conform to her supposed role as a stable, passive object. Admittedly, 'liberation' may be too bold of a term, but the magnitude of physical displacement is less important than its function as the logical consequence of the doll's active movement. "I turned round and around / and fell on my face" (2-3, emphasis added) contrasts with "I was a clockwork doll but then / ... I turned round and around" (1-2, emphasis added). While "but then" indicates a departure from the norm or status quo, "and" implies sequential progression. The doll's fall is the expected, immediate consequence of her active movement. Thus, the poet pinpoints active movement as the causal mechanism that brings about partial physical liberation.

This fall, a minor act of physical liberation, leads to a subtle dismemberment of the doll. In the archetypal blazon, the male poet's lyric dismemberment of the beloved becomes "a particular mode of control over a woman's body" (Parker 132). In "Clockwork Doll," Ravikovitch's doll dismembers (and therefore takes control of) herself. Before the more obvious blazoning (of hair, eyes, dress, and hat) discussed above, dismemberment first occurs as the logical consequence of the doll's fall. Again using Burnshaw et al.'s literal translation: after

\footnotetext{
${ }^{3}$ Burnshaw et al's translation, unlike Bloch and Bloch's translation, prioritizes words' literal meanings over preserving any sort of rhyme scheme.
} 
actively turning "to the right and to the left ... I fell [on my] face to the ground and was broken to bits" (192, [on my] is Burnshaw et al's insertion). The doll's dismemberment into her particulars, her "bits," is a rudimentary, basic blazon that could only have occurred after the doll's fall. The male-dominant order, embodied in "they," attempts to reverse this initial dismemberment by "piec[ing] [the doll] together again" (4), yet the dismemberment's power nevertheless makes the doll "become damaged goods" (7). Because all of "Clockwork Doll" is in the past tense, "become" implies significant change, even transformation: "I was a clockwork doll ... But I'd become damaged goods" (1-7). The doll has become "damaged" in relation to her status as a "good"; her brokenness indicates diminished utility for the system of commodification that "they" favor. And, a singular doll transforms into a plurality of "damaged goods," demonstrating that the doll has coopted some of dismemberment's transformative power.

Furthermore, this initial breaking into "bits" points toward the possibility of breaking free from the blazon's oppressive power dynamic. In describing the doll's state as "damaged goods," Ravikovitch uses the metaphor of "an injured twig poised for a fall" (8), "an allusion to Chaim Nachman Bialik's 'A Twig Fell' ... [where] Bialik compares himself to a tree that cannot bear fruit, an image of disconnection" (Kirsch). Here, Ravikovitch coopts a seemingly despondent metaphor to emphasize the doll's fundamental disconnect from the conventional blazon's system of objectification. In connecting herself to Bialik's “injured twig," Ravikovitch's doll places herself on the precipice of breaking free from the blazon's power dynamic. And while the doll is still an object after breaking into "bits," this initial blazon indicates both a model for empowerment and the way we should read Ravikovitch's next blazon. Movement ("to the right and to the left") leads to partial physical liberation (when the doll "fell on [her] face" (3)), which brings about a blazon ("broken to bits") that begins the doll's process of escaping the oppressive power dynamic ("damaged goods ... an injured twig poised for a fall" (7-8)).

Applying this initial model for empowerment on a larger, more ambitious scale, Ravikovitch's doll moves to become part of human society, rejecting her objectification. Just as the initial act of turning around causes her to fall, the doll's active movement of going "out to dance at the ball" (9) leads to her being physically "cast ... aside with the dogs and the cats" (10). By associating her with "the dogs and the cats," the poet further liberates the doll from the oppressive order's control, becoming more than just "damaged goods." Dogs and cats are neither the human "they" nor the objectified doll; they exist on the oppressive order's border, "cast ... aside" at the same time as they are domesticated. Unlike "damaged goods" (or "an injured twig"), dogs and cats are not objects, implying that the doll is similarly animate, though still not human. This partial liberation through placement on the human/object border is a logical intermediary in the doll's process of transforming from object to human. Movement ("I went out to dance at the ball" (9)) leads to physical liberation ("they cast me aside" (10)); the next step for empowerment is dismemberment through a blazon and the accompanying transformation into a human.

Full and complete empowerment comes through the doll's self-dismemberment in human terms. Nancy Vickers explains that description in the blazon is "a gesture of display, a separating off and a signaling of particulars destined to make visible that which is described" 
("The Blazon" 96). Conventionally, a poet uses a blazon to describe a beloved whom he has already seen; the beloved's existence inspires and motivates the blazon's subsequent creation. Yet "Clockwork Doll" reverses this relationship, using the blazon to subsequently create a reality in which the doll is human. In the concluding blazon of "my hair ... my eyes ... my dress ... [and] my hat" (12-14), the doll does not describe herself in terms of an object, but in terms of a person, with the aim of literally personifying herself. Yet a second "become" does not follow the final blazon; the previous transformation from clockwork doll into "damaged goods" was predicated upon the transformation implied by "become." This absence would seem to indicate that this final blazon does not transform the doll, making empowerment impossible.

However, if the final blazon's goal is to grant the doll personhood, then the poem's silence following the doll's dismemberment implies success. Because of her self-dismemberment, the poet-as-doll (i.e. the poem's speaker) transforms into the poet-as-person. Because she is no longer a clockwork doll, the poet can no longer be the poem's speaker, justifying the silence following the final blazon. This post-poem silence is beyond the poem's confines and, therefore, beyond the aforementioned rigidity of the sonnet form. Ravikovitch's doll has broken free from the archetypal blazon's oppressive power dynamic, even escaping its formal manifestation. The poet no longer speaks because the poet is no longer a doll.

Yet if the poem's speaker is a doll, why does she speak of her time as a doll in the past tense? The poem's temporal placement in the past complicates our understanding of the speaker's subjectivity. The above analysis of the post-poem silence assumes that the poem's speaker is the poet-as-doll. Yet if the speaker is presently a doll, she cannot also speak of when she "was a clockwork doll" in the past tense. If the poem's speaker is not the poet-as-doll, there is no reason to assume that the poet-as-person occupies the post-poem silence. Thus, the postpoem silence again seems to indicate the doll's failure to achieve self-empowerment through coopting the blazon.

However, the poem's temporal placement in the past definitively demonstrates the success, rather than failure, of the doll's transformative self-dismemberment. Bloch and Bloch's translation narrates the events of and following "that night I turned round and around" (2); the poet is normally a doll, but she begins a process of transformation "that night." Yet Burnshaw et al.'s translation indicates that the speaker is the poet-as-person, not the poet-as-doll. Literally understood, Ravikovitch's poem begins by establishing the poetic narrative's temporal location: "That night I was a clockwork doll" (Burnshaw et al. 192). The specificity of "that night" indicates that the speaker is not usually a clockwork doll; the poet-as-person narrates a specific, abnormal instance in which she "was a clockwork doll." The beloved's aforementioned lyric subjectivity, achieved through conflation with the poet, thus takes on new significance. Ravikovitch's doll does not have just any voice, but the decidedly human voice of the poem's speaker, the poet-as-person. From the poem's first line, the doll's ultimate transformation into a human is a foregone conclusion because the speaker's time as a doll is decidedly in the past. In using the past tense, the poem's speaker confirms what the aforementioned post-poem silence merely implies: the poet is no longer a doll because she transformed herself using the final 
blazon. After that blazon, the poet-as-person is silent because "that night" is over; nothing remains to be said about her time as a clockwork doll. The poet "was a clockwork doll," but that time is literally in the past; she is no longer an object.

\section{Works Cited}

Bloch, Chana and Chana Kronfeld. "Dahlia Ravikovitch: An Introduction." Prooftexts, Vol. 28, No. 3: Fall 2008. pp. 249-281. <http://muse.jhu.edu/>.

Burnshaw, Stanley, Susan Glassman and T. Carmi. “Clockwork Doll." The Modern Hebrew Poem Itself. Detroit, MI: Wayne State University Press, 2003.

Kirsch, Adam. "A Clockwork Doll." 5 February 2010. The Nerw Republic. http://www.tnr.com/book/review/clockwork-doll.

Parker, Patricia. "Rhetorics of Property: Exploration, Inventory, Blazon." Literary Fat Ladies: Rhetoric, Gender, Property. pp. 126-154. London and New York: Methuen, 1987.

Ravikovitch, Dahlia. "Clockwork Doll." Trans. Chana Bloch and Ariel Bloch. The Making of the Sonnet. Ed. Eavan Boland and Edward Hirsch. New York, NY: W.W. Norton, 2008.

Vickers, Nancy J. "Diana Described: Scattered Woman and Scattered Rhyme." Critical Inquiry, Vol. 8, No. 2: Winter 1981. pp. 265-279. http://www.jstor.org/stable/1343163.

Vickers, Nancy J. "The Blazon of Sweet Beauty's Best': Shakespeare's Lucrece." Shakespeare and the Question of Theory. Ed. Patricia Parker and Geoffrey Hartman. London and New York: Methuen, 1985. pp. 95-115. 